\title{
Intellectual Capital, Innovation and Performance: a Systematic Review of the Literature
}

\author{
Anne-Laure Mention \\ Centre de recherche public Henri Tudor \\ Avenue JF Kennedy, 29 - 1855 Luxembourg \\ Tel: 352-425-991-6821Ｅ-mail: anne-laure.mention@tudor.lu
}

Received: May 4, 2012 Accepted: May 18, 2012 Published: June 11, 2012

doi:10.5296/ber.v2i1.1937ＵRL: http://dx.doi.org/10.5296/ber.v2i1.1937

\begin{abstract}
This article provides a systematic review of the literature on the complex relationships between intellectual capital, innovation and performance. Although these concepts are clearly intertwined, there has been so far and to the best of our knowledge, no attempt to systematically review and integrate the literature examining the relationships between them. Two main streams of literature emerge: on the one hand, some literature focuses on the economic and financial effects of intellectual capital and its components on performance and on the other hand, a small set of survey-based studies aims to delineate these effects adopting a multidimensional approach to performance. Besides these two streams, there is a wealth of literature exploring the effect of isolated element of human, structural or relational capital on performance. Nevertheless, these studies rarely refer to these concepts directly and it is therefore contended that using the concept of intellectual capital may provide interesting insights to illuminate the complex relationships between firms' resources and activities to leverage its intangible assets, innovation and performance. In doing so, it provides an intellectual capital oriented framework to capture the distinctive features of innovation at firm level and hence contributes to the scarce stream of literature focusing on better identifying and delineating innovation effects on performance.
\end{abstract}

Keywords: intellectual capital, innovation, performance, systematic review, literature 


\section{Introduction}

Intangible resources and capabilities, also referred to as intellectual capital, are now widely acknowledged as the most important source of value creation and competitive advantage (Drucker, 1993; Grant, 1996). Extensive academic literature has stressed the strategic importance of leveraging and managing intellectual capital for reaching performance targets and maintaining high levels of competitiveness. Despite this recognition of the critical role of intellectual capital, much remains to be understood about its role in the value creation process itself (Schiuma \& Lero, 2008) and its effects on performance.

Innovation is another cornerstone of performance at firm-level and has long been acknowledged as a key driver of productivity and economic growth (e.g. Griffith et al., 2006). Yet, “innovations are created primarily by investments in intangibles” (Lev, 2001). Intellectual capital and innovation therefore appear closely intertwined. Accordingly, the boundaries between studies on innovation and intellectual capital are blurring since the latter can be considered as antecedents in innovation studies while some intellectual capital investigations use innovation as an outcome (e.g., Ahuja, 2000; Subramaniam \& Venkatraman, 2001; Tsai \& Ghoshal, 1998). Nonetheless, attempts to review and integrate literature on intellectual capital, innovation and performance are rare. Exploring how intellectual capital affects the innovation process and performance can thus be deemed a topical issue.

This paper aims to go beyond the fragmented literature on intellectual capital, innovation and performance by providing a systematic review of selected peer-reviewed articles. The main purpose is to categorize the prior research focusing on the effects of intellectual capital, delineating in into its main components, on performance and on innovation in view of identifying avenues for further research in this field.

This article is structured as follows. Section 2 explains in further detail the objective and scope of this study while section 3 describes the method applied to identify, select and highlight the relevant literature. After a brief presentation of some general features of the reviewed studies, section 4 provides an in-depth presentation of the findings. Section 5 concludes and derives areas for further research.

\section{Setting the Scene: Scope of the Review and Definition of Key Concepts}

This study consists of a systematic review of articles published in a selection of peer-reviewed journals on the relationship between intellectual capital, innovation and performance. More specifically, there are two main objectives: (1) identify how intellectual capital as a whole or its individual components directly and indirectly affect performance; (2) identify the role of intellectual capital and its components on the innovation process, on innovation outcome and on performance.

\subsection{Defining the Key Concepts}

Three main concepts are used in this study: intellectual capital, innovation and performance. Each concept is briefly introduced in the following subsections. 


\subsubsection{Intellectual Capital}

Definitions of intellectual capital abound. This profusion of definitions illustrates the different perspectives from which they have arisen, i.e. knowledge management, intellectual property rights management, reporting and accounting issues, financial measurement and management control and finally, innovation management. It also reflects the diversity of actors contributing to this research topic (e.g. standard-setters and accounting bodies, academics, practitioners and consultants), their main disciplinary field as well as their different interests in addressing the issue of managing, measuring, valuing or reporting intellectual capital (Mention, 2011). However, a consensus emerges on the fact that intellectual capital is a multidimensional concept, consisting of the combination of human, structural or organizational and relational resources of the firm (Meritum, 2002). In this respect, intellectual capital is more than the sum of these types of resources, which are strongly intertwined. Intellectual capital embraces all intangibles that are susceptible to generate future benefits. Lev (2001) further states that intangibles are "claims to future benefits that do not have a physical or financial embodiment”.

Intellectual capital (henceforth, IC) approaches are either static or dynamic. According to the static approach, the term IC allows capturing the stock of internal and external resources that firms possess at a particular point in time (e.g. Bontis, 1999; Bontis et al., 2002; Choo \& Bontis, 2002). In contrast, the dynamic approach to IC argues that it also covers the activities that are undertaken by firms in order to leverage this stock of resources, create value and protect new knowledge. Such activities encompass e.g. training staff, managing knowledge and conducting R\&D activities, and are expected to reinforce existing or create new stocks of intellectual capital (e.g. Kianto, 2007; Meritum, 2002).

In accordance with the scope of this study, a comprehensive definition of IC is proposed: IC is a set of internal and external resources (human, process, IT-based or enabled) that organizations mobilize and articulate, through activities, with other resources (financial and tangible) in order to further generate resources, which can be of tangible, intangible or financial nature, in their pursuit of competitive advantage. In other terms, intellectual capital covers both the stock of available resources and their activation in view of creating value. Resources are not all equally valuable and to be recognized as intellectual capital, resources must be able to generate rents that exceed their costs (also referred to as appropriability criteria in the literature, see Wade and Hulland, 2004) and experience some form of immobility (Wade \& Hulland, 2004).

Human capital (Becker, 1964; henceforth, HC) is recognized as the central component of intellectual capital. HC is the only generative intangible (Ahonen, 2000) as individuals are the ones who provide organizations with competences, engage in customer relations and are the source of intellectual property (Fincham \& Roslender, 2003). Most definitions agree that human capital relates to the competence of employees, which includes the knowledge, skills, experiences and abilities of people (Roslender \& Fincham, 2004). Thus, human capital is inseparable from its bearer (Fernandez et al., 2000). The degree of specificity and uniqueness 
of HC has been largely discussed in the literature (e.g. Lepak \& Snell, 1999), as well as the way firm-specific HC knowledge is developed. Generic HC is predominantly accumulated through individual efforts (education and experience) and is highly transferable across firms. On the opposite, firm-specific HC results from idiosyncratic learning processes (Lepak \& Snell, 1999) and is path-dependent (Barney, 1991). It refers to unique competencies and skills that individuals develop in the context of their professional activities. Most definitions emphasize the individual aspect of human capital, regardless of the context in which it is developed or mobilized. However, some advocate that knowledge is socially constructed and results from interactions with others, often referring to the concept of "social capital” and its impact on human capital development (e.g. Coleman, 1988). Nahapiet \& Goshal (1998) define social capital as the sum of the actual and potential resources embedded within, available through and derived from the network of relationships possesses by an individual or a social unit. In this study, human capital is considered mainly as an individual-level construct, and refers to individual knowledge, expertise, experience, skills, attitudes, abilities and personal networks of individuals. Consistently with the dynamic approach highlighted above, activities (e.g. training, mentoring, coaching) that aim to leverage the stock of human capital are also covered.

Structural capital (henceforth, SC) has been described as the infrastructure "that encourages the human resource to create and leverage its knowledge” (Edvinsson \& Sullivan, 1996). In other terms, its main purpose is to support the conversion of human capital into intellectual capital. Unlike human capital, structural capital is owned by the firm and can therefore be traded. Literature also refers to it as the knowledge that remains within the firms at the end of the working day (Edvinsson \& Malone, 1996). It therefore encompasses the processes embedded within firms, the collective know-how that is said to reside within the organizational routines or rules (Nelson \& Winter, 1982). Routines represent firm-specific knowledge and are the results of its collective learning (Fernandez et al., 2000). They form the organizational memory, facilitate co-ordination and support efficiency. Metaphorically, SC can be viewed as the backbone of the organization, including the organization's strategies, process and policies. Information technologies and systems, such as software and databases, are other components of structural capital as they also contain knowledge accumulated by the firms (Stewart, 1997). Structural capital also embraces corporate culture and management philosophy, which provide a framework to guide and interpret actions in the firm. Scholars have long debated whether intellectual property should be included in structural capital or considered separately. Sveiby (1997) and Stewart (1997) include intellectual property in intellectual capital while Choo \& Bontis (2002) argue that intellectual property should not be part of intellectual capital since the former can be legally protected (e.g. through patents, trademarks) and are recognized as assets in accounting while the latter (e.g. ideas, competencies, etc.) are not legally protectable and do not meet the recognition criteria set in accounting standards. This review focuses on the role of intellectual capital in the value creation and innovation process. Given the importance of intellectual property in knowledge-based economies, the definition adopted here encompasses intellectual property, notwithstanding the fact that IP receives a distinct accounting treatment than other elements of intellectual capital. 
Relational capital (henceforth, RC) refers to the ability of an organization to interact with external stakeholders. RC is broadly defined as all resources linked to the external relationships of the firm, with customers, suppliers or R\&D partners (Meritum, 2002). Originally, this form of capital was part of structural capital (Edvinsson \& Malone, 1997; Roos \& Roos, 1997). However, it emerged as a distinctive form of capital, primarily focused on relationships with customers and labeled accordingly customer capital. Later on, the concept was extended to cover all the various external connections of the firms and accordingly renamed relational capital. Reputation, which reflects the image that stakeholders have of the firm, is another key component of relational capital. This study adopts a broad definition of relational capital, encompassing the resources and activities that are mobilized and conducted by organizations when dealing with entities that are outside its boundaries.

This classification of intellectual capital will serve as a framework to categorize prior literature.

\subsubsection{Innovation}

There is a wide diversity of definitions of innovation. According to Schumpeter, the term "innovation" stresses the novelty character and can be widely applied to: a new product (good or service), a new method of production, a new market, a new source of supply or even a new organizational structure (Schumpeter, 1934). As innovation and its impact on economic performance have attracted increasing interest, the OECD has released definitions and guidelines for gathering and interpreting data on innovation and its measurement. Originally, the Oslo Manual (1992) focused only on technological product and process innovation in the manufacturing sector. Given the increasing importance of services in OECD countries and the growing concern that innovation was not properly captured by technological product and process innovation, marketing and organizational innovation types were introduced in the second edition of the Manual (1997).

According to the latest revision of the Oslo Manual (OECD, 2005), an innovation is "the implementation of a new or significantly improved product (good or service), or process, a new marketing method, or a new organizational method in business practices, workplace organization or external relations”. The Manual therefore acknowledges the existence of four types of innovation: product (either good or service), process, marketing and organizational innovations.

Literature also acknowledges two dimensions of innovation: innovation as a process and innovation as an outcome (Crossan \& Apaydin, 2010). Innovation as a process is concerned with the "how" question whereas innovation as an outcome pertains to the "what" perspective. Innovation as a process considers where the innovation process takes place (inside the boundaries of the firm or within a network), what are the internal and external drivers of innovation (e.g. availability of resources and knowledge, market opportunity, compliance to a new standard), and what are the sources of innovation (internal and external). Innovation as an outcome focuses on the type of innovation (product, process, organizational, marketing), the magnitude of innovation (radical or incremental), and the referent (firm, market, industry) 
used to assess the degree of novelty. Although innovation as a process precedes innovation as an outcome, this perspective has so far received much less attention than the other (Crossan \& Apaydin, 2010).

The nature of the innovation process and its conceptualization has drastically evolved over time. In an in-depth historical perspective, Rothwell (1992) identifies 5 main generations of innovation models, ranging from linear to highly complex and interactive ones. First generation is linear. It relies on the science-push model and emphasizes the role of R\&D. Design, engineering, manufacturing and marketing processes are described as a flow. Second generation model, also called market-pull, highlights the client needs. In this generation, innovation is closed linked to marketing strategies. Third generation model is introduced in the 1980s. Also labeled the "coupling model”, it acknowledges the interaction between elements and suggests the existence of feedback loops between them. The main underlying idea is to link R\&D and marketing, as both technology push and market pull are considered. Fourth generation focuses on the integration within the firm, and outside its boundaries, both upstream with key suppliers and downstream with demanding and active customers. This model stresses linkages and alliances, and is also called the parallel model. Finally, fifth generation sees innovation as a multi-actor process, requiring high levels of integration, intra and inter-firm alike (Tidd et al., 2005). Information technologies play a crucial role and facilitate this integration. Quite recently and following the same trend (i.e. integration), the “Open Innovation” concept has emerged (Chesbrough, 2003). Chesbrough \& al. (2006) define Open Innovation as: "the use of purposive inflows and outflows of knowledge to accelerate internal innovation, and expand the markets for external use of innovation, respectively. Open Innovation is a paradigm that assumes that firms can and should use external ideas as well as internal ideas, and internal and external paths to market, as the firms look to advance their technology". This evolution of innovation process conceptualization occurred parallel to the broadening of the concept and scope by the OECD.

\subsubsection{Performance: From Unidimensional to Multidimensional Construct}

Though central in management literature, the concept of performance remains ambiguous and its scope is still largely debated. Venkatraman \& Ramanujam (1986) delineate the performance concept and identify three domains: financial performance, business performance and organizational effectiveness. The narrowest conception - financial performance - concentrates on "outcome-based financial indicators that are assumed to reflect the fulfillment of the economic goals of the firm” (Venkatraman \& Ramanujam, 1986). Typical indicators monitored include profitability (i.e. measured by ratios such as return on investment, return on equity, return on sale), earnings per share and market values (i.e. market to book ratio, Tobin's Q). Though apprehending performance only through financial measures may appear slightly restrictive, it remains the dominant approach in the literature (e.g. Chenhall, 1997; Davis \& Peles, 1993; Ittner \& Larcker, 1997).

Criticisms of this conventional approach to performance measurement have increased over time, and relying on such traditional measures has been reckoned to "encourage short-sighted actions" (Merchant \& Burns, 1986). Atkinson et al. (1997) argue that "performance 
measurement systems based primarily on financial performance measures lack the focus and robustness needed for internal management and control” (Atkinson et al., 1997).

A broader conceptualization of performance encompasses indicators of operational (i.e. non financial) performance. Typical of this approach is to scrutinize indicators such as market share and market development, product quality, measures of technological efficiency, assuming that these reflect the key success factors of the firm and thus may lead to future financial performance (Ittner \& Larcker, 1998; Mia \& Clarke, 1999).

In terms of performance measurement, the Balanced Scorecard (Kaplan \& Norton, 1992), the Performance Prism (Neely et al., 2002) and the Business Excellence Model (EFQM, 1999) are frameworks that exemplify the accrued focus on performance as a multifaceted concept. These frameworks suggest the existence of cause-and-effect relationships between the various facets of operational and financial performance.

Fitzgerald et al. (1991)'s framework follows a similar logic. Based on a study on performance measurement in the service sector, Fitzgerald et al. (1991) propose a simplified conceptualization of performance, made of results and determinants. The underlying assumption is the existence of two basic performance measures in any firm: results-oriented measures (competitiveness, measured through e.g. market positioning and sales growth, and financial performance) and determinants of these results (i.e. quality, flexibility, resource utilization and innovation).

Finally, the broadest approach to performance is organizational effectiveness (OE), developed in the field of Organizational Theory. This concept takes into consideration the "multiple and conflicting nature of organizational goals and the influence of multiple stakeholders" (Cameron \& Whetten, 1983 cited by Venkatraman \& Ramanujam, 1986). As argued by Saulquin \& Schier (2005), the boundaries of companies have also become increasingly permeable and companies have increasingly relied on their partnerships. Henceforth, "the company is the place of meeting of the divergent motivations of the actors who take part in its development" (Saulquin \& Schier, 2005). With respect to measurement issues, Campbell (1977) reviews the literature and identifies 30 different criteria related to organizational effectiveness, such as quality, job satisfaction, motivation, absenteeism and productivity. In this seminal work, the author raises concerns about the selection process of a set of criteria, which is inevitably affected by subjectivity bias. Based on prior works by Morin et al. (1994), Savoie \& Morin (2000) propose a five-dimension model for organizational effectiveness, covering the economic efficiency, value of human resources, legitimacy and sustainability of the organization and finally, the political aspect (i.e. satisfaction of external stakeholders).

Atkinson et al. (1997) propose a performance measurement system based on a stakeholder approach, and in a directional approach to performance measurement, clearly identify two groups of stakeholders which do not exert similar power over the organization. Primary objectives are set by primary stakeholders (i.e. firms' owners) while secondary objectives "are instrumental in helping the company achieve its primary objectives".

In this literature review, the focus is primarily on financial and business performance. 


\section{Method}

The here applied method is "systematic literature review". According to Mulrow (1994), "systematic review has been argued to provide the most efficient and high quality method for identifying and evaluating extensive literatures". Systematic reviews, usually applied in the medical sciences, have recently gained momentum in the management literature (Denyer \& Neely, 2004). They differ from traditional narrative reviews by adopting a replicable, rigorous, scientific and transparent process (Cook et al., 1997). Consequently, this approach allows minimizing bias and subjectivity. Systematic literature reviews aim to identify key scientific contributions to a field or a question and present the results in a descriptive manner. Unlike meta-analyses, they do not rely on statistical procedures to summarize the findings and analyze the data (Tranfield et al., 2003). Following the recommendations of Tranfield et al. (2003), the stages for this review include: development of clear and precise objectives; setting of explicit inclusion criteria; comprehensive search of all potentially relevant articles in pre-defined journals; assessment of study quality; synthesis of individual studies using an explicit analytical framework and finally, comprehensible presentation of the results.

Although academic research on intellectual capital is growing at a steady rate, it remains a relatively emergent domain (Serenko \& Bontis, 2004). IC research usually encompasses a multidisciplinary approach (Serenko et al., 2010). Since IC is not recognized as an academic discipline by the scientific community and remains fairly young, IC-focused journals do not (yet) appear in widely used journal rankings (e.g. Thomson ISI Web of Knowledge). A well-known limitation of systematic reviews is linked to the "publishing preferences of particular disciplines”. Therefore, restricting the systematic review to high level journals may potentially lead to an overlook of relevant contributions. To address this issue, a mitigation measure was put in place (Pittaway et al., 2004). It consisted in adding to the data sources the Journal of Intellectual Capital, which has been publishing research works on this topic since 2000. Based on a multi-criteria analysis, this journal has been ranked and scored 2nd out of 20 journals in the field, by 223 distinguished active researchers in the field of Knowledge Management/Intellectual Capital according to recent study applying scientometric principles (Serenko et al., 2010).

\subsection{Inclusion Criteria}

In order to be included in this review, a study had to comply with the following criteria:

- Be an article published in a peer reviewed journal. Thus, other publication forms (conference proceedings, books, newspaper articles, unpublished works, etc.) were not considered;

- Consider firm-level performance as the dependent variable. Consistently with the definition provided above, performance is considered as a multidimensional concept and can be assessed from both financial and non financial perspectives. Articles which considered performance as an independent variable (i.e. an explanatory variable of another phenomenon such as exportations, survival of firms) and articles which studied performance using another unit of analysis (e.g. team, individual-level) were not included. 
- Refer to intellectual capital explicitly or at least to one of its component.

\subsection{Data Sources and Studies Selection}

The review strategy is a multi-stage process consisting of the identification of keywords, which are primarily derived from prior literature. Intellectual capital, innovation and performance have been used as keywords within the search function "All fields" of SCOPUS. Although this approach generated a large amount of noise amongst the retrieved titles, it was deemed appropriate as the exclusive use of the "Article titles, abstracts and keywords" search option obviously led to an overlook of relevant contributions.

A computerized search using these keywords was conducted in 11 top-level journals. These journals pertain to the following domains: strategy and management (4), innovation and entrepreneurship (4), general economics and general management (1), marketing (1), and a journal dedicated to services, according to the categorization of journals in Economics and Management provided by the Committee 37 of the CNRS, as illustrated by Table 1 . By doing so, 448 potential articles were identified. In addition, 125 potentially relevant articles were identified in the Journal of Intellectual Capital.

Table 1. Selected sources

\begin{tabular}{|c|c|c|c|}
\hline Journal & CNRS & Domain & $\begin{array}{l}\text { Number of } \\
\text { articles }\end{array}$ \\
\hline Academy of Management Journal & 1 & Strategy \& Management & 45 \\
\hline Academy of Management Review & 1 & Strategy \& Management & 37 \\
\hline Strategic Management Journal & 1 & Strategy \& Management & 71 \\
\hline Journal of Management Studies & 2 & Strategy \& Management & 55 \\
\hline $\begin{array}{lll}\text { Journal of } & \text { Product } & \text { Innovation } \\
\text { Management } & & \\
\end{array}$ & 1 & Innovation \& Entrepreneurship & 18 \\
\hline R\&D Management & 3 & Innovation \& Entrepreneurship & 41 \\
\hline Technovation & 3 & Innovation \& Entrepreneurship & 34 \\
\hline $\begin{array}{l}\text { International Journal of Technology } \\
\text { Management }\end{array}$ & 3 & Innovation \& Entrepreneurship & 88 \\
\hline Management Science & 1 & $\begin{array}{l}\text { General Economics, General } \\
\text { Management }\end{array}$ & 27 \\
\hline Journal of Business Research & 3 & Marketing & 21 \\
\hline Services Industries Journal & - & - & 11 \\
\hline
\end{tabular}

Sources for the literature review with CNRS ranking

This uneven distribution of selected journals amongst the disciplines is motivated by the willingness to focus this literature review on 2 perspectives: strategy \& management and innovation \& entrepreneurship. Other disciplines, which also investigate intellectual capital and performance, were not considered and this has to be acknowledged as a limitation of the present work.

These citations identified were then reviewed in a three-stage process according to inclusion and exclusion criteria. The first stage consisted in analyzing the titles and excluding 
duplicates, book reviews or commentaries. The second stage analyzed the abstract according to the inclusion criteria. Theoretical, methodological and empirical papers using qualitative or quantitative methodologies are considered. Other criteria are as follows: some information on research design is provided, the question of generalizability is raised, some implications for practice are mentioned, and an abstract is provided. A number of studies (387) were then excluded based on abstracts and titles. 186 Relevant articles were then retrieved for an in-depth evaluation of the full text. In the third stage, full articles were screened and some did not meet the inclusion criteria. This left a total of 145 studies which matched all the inclusion criteria and were included in this review.

\section{Findings}

When considering the general features of analyzed studies, hitherto, there are two main streams of studies investigating the relationship between intellectual capital and performance.

A first set of studies relies on objective performance measures, available in financial accounts and produce an overall assessment of the value-creating efficiency of intellectual capital (e.g. Chen, 2009; Ghosh \& Mondal, 2009; Shiu, 2006; Ting \& Lean, 2009). This indicator-based method (called VAIC ${ }^{\mathrm{TM}}$, Value Added Intellectual Coefficient) has been widely used, across sectors and countries, and provides a standardized measure, easy to understand and allowing benchmarking.

Another stream of studies (e.g. Bontis, 1998; Bontis et al., 2000; Cabrita \& Bontis, 2008; Hermans \& Kauranen, 2005; Jardon \& Martos, 2009) relies on perceptual measures of IC and performance, usually collected through dedicated questionnaires administered to key informants (Philips, 1981). Some studies adopt a mixed approach, as they combine managers' perceptions on intellectual capital with factual and objective performance data (e.g. Cohen \& Kaimenakis, 2007; Wang \& Chang, 2005, Youndt et al., 2004).

Next to the investigation of the relationship between intellectual capital and performance, studies investigate the effects of individual components of intellectual capital on performance, the latter taking the form of financial or organizational performance. In other terms, they disentangle the IC concept and analyze the effects of isolated elements on performance. Again these studies can be divided into several subsets: those that explore the relationship between an individual component of IC (being HC, SC or RC, or even a subcomponent) and those that analyze the effects of combined elements of HC, RC and SC on performance.

A final set of studies examines the effects of IC or some of its components on innovation, where innovation is analyzed either from a process perspective (e.g. Emden et al., 2006; Griffith, 2006; Herrara et al., 2010) or from an outcome perspective (e.g. Chang, 2003; Monjon \& Waelbroeck, 2003; Somaya et al., 2008). Selected studies are classified accordingly in Figure 1. 


\begin{tabular}{|c|c|c|c|c|}
\hline \multirow[t]{2}{*}{ Intellectual capital } & & \multirow[t]{2}{*}{ Performance } & \multicolumn{2}{|c|}{ Innovation } \\
\hline & & & Process & Outcome \\
\hline \multirow[t]{4}{*}{ Human capital } & Competencies, skills & $\begin{array}{l}\text { Nordhaug (1998) } \\
\text { Mincer (1997) }\end{array}$ & Adams et al. (2006) & Selvarajan et al. (2007) \\
\hline & Mobility & Dess \& Shaw (2001) & $\begin{array}{l}\text { Herrara \& Munoz-Doyague } \\
(2010)\end{array}$ & Somaya et al. (2008) \\
\hline & Individual networks & Florin et al. (2003) & & Wincent et al. (2010) \\
\hline & HR practices & $\begin{array}{l}\text { Collins \& Clark (2003) } \\
\text { Delery \& Doty (1996) }\end{array}$ & & $\begin{array}{l}\text { Chen \& Huang (2009) } \\
\text { Koschatzky et al. (2001) }\end{array}$ \\
\hline \multirow[t]{5}{*}{ Structural capital } & Intellectual property & $\begin{array}{l}\text { Artz (2010) } \\
\text { Bollen et al. (2005) }\end{array}$ & $\begin{array}{l}\text { Lev (2001) } \\
\text { Ahuja \& Katila (2001) } \\
\text { Artz et al. (2010) }\end{array}$ & Lev (2001) \\
\hline & Information systems & Brynjolfsson \& Hitt (2000) & & \\
\hline & Knowledge Management & $\begin{array}{l}\text { Darroch (2005), Marques \& } \\
\text { Simon (2006) }\end{array}$ & Adams et al. (2006) & \\
\hline & $\begin{array}{l}\text { Organizational structure } \\
\text { and culture }\end{array}$ & & Damanpour (1991) & \\
\hline & Information sources & Griffith et al. (2006) & Griffith et al. (2006) & $\begin{array}{l}\text { Laursen \& Salter (2006) } \\
\text { Sokfta \& Grimpe (2010) }\end{array}$ \\
\hline \multirow[t]{3}{*}{ Relational capital } & Inter-firm co-operation & Asakawa \& Nakamura (2010) & Emden \& Calantone (2006) & $\begin{array}{l}\text { Chang (2003) } \\
\text { Clark (1989) }\end{array}$ \\
\hline & Science-based co-operatid & Kaufmann \& Tödling (2001) & & Monjon \& Waelbroeck (2003) \\
\hline & Intra-firm co-operation & Martin \& Eisenhardt (2010) & & Tsai \& Goshal (1998) \\
\hline
\end{tabular}

Figure 1. Selected studies on IC and its effects on Performance, Innovation Process and Innovation Outcome

The theoretical background for most studies is the Resource-Based View (Penrose, 1959; Wernerfelt, 1984). As one of the most influential theories in management, RBV argues that a firm is able to achieve sustainable competitive advantage from its (static) resources, dynamic capabilities and knowledge (Barney, 1991). Differences in profitability across competing firms are thus due to differences in the resources they possess, acquire and control and in the ways these resources are deployed. These resources must meet four attributes: valuable, rare, inimitable or imperfectly imitable, non substitutable (Barney, 1991). Amongst this resource base, intellectual capital has become increasingly important.

The dominant epistemology is positivism, although some studies refer to constructivism. The vast majority of innovation studies are anchored in confirmatory research while IC-related studies tend to be more exploratory, which may be attributable to the fact that IC research remains relatively new. Quantitative methodology is by far more common. Notable exceptions are Jassawalla \& Sashitall (1998) and Martin \& Eisenhardt (2010), whose research is case-study based.

Survey-based studies exploring the relationship between IC and performance have primarily focused on knowledge intensive sectors, such as ICT and software, pharmaceutical and more recently, banking. A notable fact is that $\mathrm{VAIC}^{\mathrm{TM}}$ studies frequently concentrate on financial firms, followed by high tech industries (e.g. Goh, 2005; Kamath, 2007; Kamath, 2008; Shiu, 2006; Ting \& Lean, 2009).

Industry-wise, innovation studies generally focus on manufacturing firms, and usually cover 
high technology sectors, such as pharmaceutical, telecommunications or biotechnologies. This is consistent with the original approach to innovation, as driven by $R \& D$ and technologically-oriented. However, to certain extent, service firms have started to be covered along with manufacturing firms over the last decade. This responds to the call for further research in services, given their accrued importance both in terms of value added and employment growth in developed countries.

Empirical analyses have been conducted in both large and small firm settings, though larger firms have clearly captured more attention. Public sector organizations are rather neglected (e.g. Sua et al., 2009).

Country-wise, North America, Australia, UK and Nordic countries dominate in the empirical literature. This observation is consistent with that reported by Serenko \& Bontis (2004) indicating that USA, UK and Australia researchers are the most productive contributors to IC literature.

The following subsections will introduce the findings, starting with an in-depth presentation of studies investigating IC and performance, then IC, innovation and performance and will be followed by subsections dedicated to the presentation of studies focused on one component of IC and its effect on performance.

\subsection{Intellectual Capital and Performance}

There are a limited number of studies investigating the relationship between intellectual capital and performance. Two main streams can be identified: an aggregated indicator reflecting a holistic approach to intellectual capital (VAIC ${ }^{\mathrm{TM}}$ ) and survey-based studies using measurement and structural models. The following subsections introduce both streams and present the main findings of these studies.

\subsubsection{VAIC VM $^{\mathrm{TM}}$ Studies}

A widely used approach to investigate the relationship between intellectual capital and performance is the Value Added Intellectual Coefficient (henceforth, VAIC ${ }^{\mathrm{TM}}$ ). Developed by Ante Pulic (1998), VAIC $^{\mathrm{TM}}$ provides a measure of the value creation efficiency of a company. This aggregated indicator shows how much new value is created by each monetary unit invested in physical, financial and intellectual resources. VAIC ${ }^{\mathrm{TM}}$ basically results from the sum of three components: human capital efficiency, structural capital efficiency and capital employed efficiency (consisting of financial and physical capital efficiency). The better a company's resources have been exploited the higher the company's coefficient will be (Pulic, 2000).

These components can be computed following the procedure described below.

According to the VAIC ${ }^{\mathrm{TM}}$ model, the value added is computed as outputs (i.e. total income) minus inputs (i.e. cost of bought-in material, components and services).

Value added can be also calculated as follows: VA $=\mathrm{P}+\mathrm{C}+\mathrm{D}+\mathrm{A}$, where $\mathrm{P}$ describes operating profits, $\mathrm{C}$ employee costs (the salaries and the social expenses of staff) and $\mathrm{D}$ and $\mathrm{A}$, 
depreciation and amortization of assets, respectively.

Human capital (HC) is calculated as the sum of all salaries and structural capital (SC) is calculated by subtracting HC to VA:

$$
\mathrm{SC}=\mathrm{VA}-\mathrm{HC}
$$

VAIC does not consider expenditures on employees as a part of input. This denotes that expenses related to employees are not treated as cost but represent an investment. As a result, human capital efficiency (HCE) may be expressed as the amount of value added generated per unit of money invested in employees and is computed as follows:

$$
\mathrm{HCE}=\mathrm{VA} / \mathrm{HC}
$$

Similarly, structural capital efficiency (SCE) is calculated as follows:

$$
\mathrm{SCE}=\mathrm{SC} / \mathrm{VA}
$$

SCE indicates how much of the company's value added is generated by structural capital.

Capital employed efficiency (CEE) is obtained by dividing VA by CE (capital employed):

$$
\mathrm{CEE}=\mathrm{VA} / \mathrm{CE}
$$

CEE describes how much of the company's value added is generated with the capital employed.

Finally, VAIC ${ }^{\mathrm{TM}}$ is obtained by adding HCE, SCE and CEE. Intellectual capital efficiency (ICE) is of course the addition of HCE and SCE.

As highlighted by Chan (2009a), VAIC ${ }^{\mathrm{TM}}$ presents numerous benefits. The inputs for VAIC $^{\mathrm{TM}}$ are publicly available data, audited and reliable. The computation process is straightforward and based on a standardized procedure. The output is useful and informative to all stakeholders and can be used for benchmarking purposes across firms or industries. Nevertheless, VAIC ${ }^{\mathrm{TM}}$ also faces criticisms such as the existence of noise in the figures used (e.g. Brennan, 2001) or the approach, qualified as restrictive, to capture human capital by using wages exclusively.

VAIC $^{\mathrm{TM}}$ has been used in a number of studies investigating the link between IC and performance (e.g. Calisir et al., 2010; Diez et al., 2010; Kujansivu and Lönnqvist, 2007; Mavridis 2004; Yalama \& Coskun, 2007).

These studies have been conducted in different countries and across industries. Various measures of performance have been considered: return on assets (profitability), asset turnover (productivity) and market to book ratio (market valuation), return on equity, revenue growth, and employee productivity.

Overall, the vast majority of studies find a positive relationship between IC and performance, using different measures of performance. Based on more than 4000 observations over 11 years, Chen et al. (2005) find a positive relationship between IC and the four performance measures (Return on assets, Return on equity, Growth in revenues, Employee productivity). 
Similarly, Shiu (2006) demonstrates a positive relationship between VAIC and ROA, consistently with Ghosh \& Mondal (2009) and Ting \& Lean (2009).

In contrast, Firer \& Williams (2003), followed by Shiu (2006) and Chan (2009) find that HCE has a negative relationship with asset turnover and market to book ratio. This finding suggests that firms making the most of their human capital may face negative effects on performance. The effect of SCE on performance is challenging, as some find a positive relationship (e.g. Chan, 2009; Chen et al., 2005), while others observe a negative but non-significant relationship (e.g. Ting \& Lean, 2009). CEE is usually found to have a positive impact on performance, whatever the measure considered, with the notable exception of Appuhami (2007), who concluded that the relationship between CEE and capital gain on shares was negative.

\subsubsection{Survey Based Studies}

The relationship between intellectual capital and performance has also been investigated based on perceptions rather than facts (i.e. accounting data, as in $\mathrm{VAIC}^{\mathrm{TM}}$ ). The use of subjective measures in management research is fairly common. Despite the possible respondent bias in the case of the perceptual measures, consistency between executive's perceptions of performance and objective measures has been evidenced (e.g. Venkatraman \& Ramanujam, 1986). A significant proportion of firm-level analysis of the relationship between IC and performance has been conducted using a dedicated survey instrument developed by Bontis (1998). In this study, intellectual capital is a second-order multi-dimensional concept, consisting of three components: human, structural and relational capital. Bontis (1998) defines the three components as follows. The essence of human capital is the human intellect and is therefore highly difficult to codify. Its scope lies internal to the mind of the employee. The essence of structural capital is the knowledge embedded within the routines of an organization. It contains elements of efficiency, transaction times, procedural innovativeness and access to information for codification into knowledge. It also supports elements of cost minimization and profit maximization per employee. Its scope is internal to the firm. The essence of customer capital is knowledge embedded in relationships external to the firm. Its scope lies external to the firm and owing to its nature, it is the most difficult to codify. Performance is assessed with 10 financial and non financial measures, referring to industry leadership and market positioning, innovative performance, profitability, growth and overall success.

The operationalization of the four constructs (human, structural, relational capital and business performance) is achieved with 63 items, which were identified by a thorough literature review. A seven-point Likert scale (strongly disagree to strongly agree) for each item has been used. The survey was originally administered to MBA students in Canada, and further used in different countries (Malaysia, Portugal, Jordan) and settings (banking, pharmaceutical). Both the direct and indirect effects of each construct on business performance have been explored, with mixed results, as table 3 illustrates. Empirical evidence of interaction effects remains scarce. 
Table 3. Selected survey-based studies

\begin{tabular}{|c|c|c|c|c|}
\hline & $\begin{array}{l}\text { Bontis, } \\
1998\end{array}$ & Bontis et al., 2000 & $\begin{array}{l}\text { Bontis \& Cabrita, } \\
2008\end{array}$ & $\begin{array}{l}\text { Sharabati et al., } \\
2010\end{array}$ \\
\hline $\mathrm{HC}->\mathrm{SC}$ & 0.492 & $\begin{array}{l}0.525 * * \\
0.304 \mathrm{~ns}\end{array}$ & 0.759 & 0.659 \\
\hline $\mathrm{HC}->\mathrm{RC}$ & 0.499 & $\begin{array}{l}0.799 * * \\
0.798 *\end{array}$ & 0.396 & 0.687 \\
\hline $\mathrm{RC}->\mathrm{SC}$ & 0.197 & $\begin{array}{l}0.496^{*} \\
0.441^{* *}\end{array}$ & - & - \\
\hline SC->RC & - & - & 0.399 & 0.699 \\
\hline RC-> Perf & 0.639 & - & 0.266 & 0.670 \\
\hline HC-> Perf & - & - & & 0.647 \\
\hline SC-> Perf & 0.508 & $\begin{array}{l}0.262 * \\
0.105 * *\end{array}$ & 0.423 & 0.557 \\
\hline $\begin{array}{l}\text { Interaction } \\
\text { effects }\end{array}$ & & & $\begin{array}{l}0.047 \mathrm{~ns}(\mathrm{HC} * \mathrm{RC}) \\
0.047 \mathrm{~ns}(\mathrm{HC} * \mathrm{SC}) \\
0.033 \mathrm{~ns}(\mathrm{RC} * \mathrm{SC})\end{array}$ & \\
\hline Sample & $\begin{array}{l}64 \quad \text { MBA } \\
\text { students }\end{array}$ & $\begin{array}{l}107 \text { respondents, Services (64) } \\
\text { and non service industries (43) }\end{array}$ & $\begin{array}{l}253 \text { respondents } \\
\text { banking sector }\end{array}$ & $\begin{array}{l}132 \text { managers } \\
\text { pharmaceutical }\end{array}$ \\
\hline Country & Canada & Malaysia & Portugal & Jordan \\
\hline
\end{tabular}

*Service **non service Ns = non significant - Effects of IC on performance based on Bontis’ survey

Adopting a similar approach, but using another survey instrument, Jardon and Martos (2009) explore the direct and indirect effects of intellectual capital on performance in 113 Argentinean SMEs active in the wood industry. Their definition of performance is slightly wider than Bontis' as it encompasses aspects of innovation capacity, transfer of new technologies and cost reductions. They conclude that structural capital is the only dimension of intellectual capital directly affecting performance. They also confirm the positive effect of relational on structural capital, as well as the positive effect that human capital exerts both on structural and relational capital. Therefore, both human and relational capital indirectly affect performance.

Investigating the same relationships in the context of 52 knowledge-intensive SMEs of the service sector, Cohen \& Kaimenakis (2007) demonstrate that human capital is positively related to both structural and relational capital. They find no evidence that structural and relational capitals are positively related. Relying on financial data instead of perceptions (i.e. profit after tax and sales per employee), they conclude that hard (i.e. objectively measurable assets so as to derive a monetary value, to some extent) and functional (i.e. distinct parameter that is expected to increase the efficiency in performing tasks and thus improve productivity) intellectual capital elements affect corporate performance, while the effects of soft (i.e. cannot be observed or defined in as straightforward manner) assets on corporate performance are inconclusive.

Similarly to Cohen \& Kainenakis (2007), Tseng \& Goo (2005) rely on objective performance 
measures (VAIC, Tobin's Q and Market-to-book ratio) to examine the relationship between IC and corporate value in 81 manufacturing firms in Taiwan. In their conceptualization of intellectual capital, they introduce the innovation capital, which covers innovation and technological ability and intellectual property. Their results confirm the positive effects of innovation and relational capital on corporate value but fail to indicate similar effects for organizational capital. Human capital is found to exert a positive influence on innovation, organizational and relational capital, while organizational capital affects positively innovation and relational capital. Finally, innovation capital also influences positively relational capital.

Wang \& Chang (2005) find evidence that human capital is the most important element of intellectual capital in Taiwanese IT organizations, as it affects directly both innovation and process capital. In turn, process capital affects directly customer capital and further on performance, while innovation capital has an indirect effect on customer capital, through process capital, and consequently on performance. Their study uses factual measures for each of the constructs, e.g. return on assets for performance, R\&D expenses for innovation capital, advertising expenditures for customer capital, employee turnover for human capital and administrative expense per employee for process capital. In a similar setting, Yang \& Kang (2008) confirm the interaction effects of innovation and customer capital on performance in high tech firms, although the effect of customer capital is lower among these firms than for their low tech counterparts. The effect of innovation capital remains stable, whether firms belong to high tech or low tech manufacturing sectors.

Hermans \& Kauranen (2005) empirically verify the effect of intellectual capital on anticipated future sales of 72 SMEs belonging to the biotechnology industry in Finland. They conclude that 2 IC-related factors, both factors being a combination of items related to human, relational and structural capital, systematically explain the anticipated future sales.

Restricting the performance exclusively to new product development (henceforth, NPD), Chen et al. (2006) find evidence that all three components of intellectual capital affect new product development performance in Taiwanese manufacturing firms. They conclude that these relationships are even stronger when the growth rate of the industry is higher.

Youndt et al. (2004) explore the relationship between intellectual capital profiles and firm performance, using accounting-based and market measures (i.e. financial returns calculated using ROA and ROE, and Tobin's Q). Their results indicate that a small group of outperforming firms exhibit high levels of human, social and organizational capital (referred to as HC, SC and OC). However, most firms focus primarily on a single dimension of IC and a small group of underperforming firms have very low levels of the 3 IC dimensions. They further investigate the relationship between investments in human resource management (HRM), information technology (IT) and research and development (R\&D) and different intellectual capital profiles (i.e. IC profiles exhibiting a higher level of a specific dimension). They conclude that HRM investments tend to be more important in firms presenting profiles with high HC and SC. Investments in IT are higher in firms with high profiles in SC but unexpectedly, not in firms characterized by higher levels of OC. High levels of all types of investments also characterize outperforming firms exhibiting high levels of each type of 
capital. Results for R\&D investments are less conclusive and provide only minor support for the hypothesis that higher level of $R \& D$ intensity would be found in profiles with higher levels of HC and OC (Youndt et al., 2004).

Investigating a large sample of US commercial and personal banks, Reed et al. (2006) find evidence that human capital interacts with organizational capital and internal social capital to positively affect financial performance in personal banks. In contrast, interactions between human capital and external social capital and between organizational capital and internal social capital negatively affect performance in personal institutions. None of the construct has main and significant effect on financial performance. In commercial banks, results slightly differ. Whereas internal social capital negatively influences performance, external social capital has a positive effect on the dependent variable, thereby stressing the importance of strong external ties within the business community for the selling of commercial banks' services.

Besides the analysis of direct and interaction effects of intellectual capital components on performance, prior research has also investigated the mediating role of organizational learning capability (Hsu \& Fang, 2009) and intellectual property (Bollen et al., 2005). In a similar vein, Wu et al. (2008) confirm the mediating role of intellectual capital and the moderating role of social capital and entrepreneurial orientation on innovation.

\subsection{Intellectual Capital, Innovation and Performance}

The combined effects of human and/or structural, and/or relational capital on the innovation process, outcome and on performance have been investigated in several settings (SMEs, large firms), sectors (high tech industries, healthcare, lodging industry) and countries (USA, Nordic countries, Australia). Selected studies focusing on the analysis of IC on innovation process (Prajogo \& Ahmed, 2006), innovation outcome (Jassawalla \& Sashitall, 1998; Prajogo \& Ahmed, 2006; Smith et al., 2005; Subramaniam \& Youndt, 2005; Wu et al., 2007) and performance (Hayton, 2005; Mol \& Birkinshaw, 2009; Tseng et al., 2008) are briefly presented below.

Concentrating on technology firms, Smith et al. (2005) assess how organization member's ability to combine and exchange knowledge (educational level, intensity of direct contacts and ties within organization) and how the organizational climate for risk taking and teamwork affect the rate of product and service introduction. In a similar context, Hayton (2005) sheds light on the role of top management diversity and organizational reputation on entrepreneurial performance, whereas the effect of intellectual property on innovation and on performance is insignificant. Also concentrating on new product development in high tech firms, Jassawalla \& Sashittal (1998) propose a conceptual framework that relates factors that seemingly affect cross-functional collaboration in new product development (NPD) to the level of cross-functional collaboration achieved in the NPD process. Their framework suggests that individual-level characteristics (propensity to cooperate, openness to change, level of trust) and organizational level ones (priority set to co-operation by top management, and the level of autonomy granted to collaborators) affect the level of collaboration and its outcome on the NPD process. 
Joint efforts towards human, structural and relational capital development lead to higher overall level of innovation and performance, also in non knowledge-intensive businesses such as the lodging sector (Tseng et al., 2008).

Focusing on organizational innovation, Mol \& Birkinshaw (2009) find that their introduction is affected by contingent factors (size, geographical scope of the market). The level of education of the workforce and the variety of information sources to which the firm has access also influences the introduction of organizational innovations. Their findings indicate that such innovation coincides with higher future performance, in the form of productivity growth.

Prajogo \& Ahmed (2006) explore the relationship between innovation stimulus, which consists of four constructs (leadership, people management, knowledge management and creativity management), innovation capacity and innovation performance. They show that the relationship between innovation stimulus and performance is fully mediated by innovation capacity. In order to achieve high innovation performance, firms must first develop the cultural and behavioral practices for innovation. Wu et al. (2007) demonstrate that structural and relational capital fully mediate the effects of human capital on innovative performance in the Taiwanese electronic and IT industry.

In their investigation of 93 US firms, Subramaniam \& Youndt (2005) demonstrate that structural capital positively affects incremental innovative capability, while human capital is negatively associated with radical innovative capability. Though, when interacted with social capital, human capital positively influences radical innovative capability.

Next to these studies explicitly referring to the role of intellectual capital in the innovation process and on the innovation outcome, an extant body of knowledge focuses on the links between innovation and performance at firm-level and lies beyond the scope of this review.

A final word should be devoted to studies relating the level of voluntary intellectual capital disclosure and capital market figures. These studies argue that the traditional accounting framework is inadequate since it conveys little information on intangible assets, deemed to play a critical role in the value creation process. Consequently, they challenge the ability of the accounting framework to meet its main objective, which is to provide information for making economic decisions on the financial position and performance of the firm, as stated by the Financial Accounting Standard Board (FASB, 1978). Typically, these studies have sought to investigate the usefulness of intellectual capital disclosure on credit risk analysis (e.g. Guimon, 2005), investment decision-making process and other market data such as market capitalization and market-to-book values (e.g. Abdolmohammadi, 2005; Vergauwen et al., 2007). These studies usually exploit different intellectual capital disclosure indexes, which make the results basically incomparable, and produce mixed and inconclusive evidence. So far, the relationship between the disclosure level and performance seems to remain unexplored.

\subsection{Human Capital, Innovation and Performance}

The relationship between human capital and performance can be traced back to many streams 
of research, including economic human capital theory (Becker, 1964; Schultz, 1961), resource-based theories (Barney, 1991), human resource management (e.g. Jackson \& Schuler, 1995), organizational learning (Argyris \& Schön, 1978) and knowledge management (Nahapiet \& Goshal, 1998).

The influence of individuals on the economic performance of firms has been widely investigated. Individual's competencies, knowledge and skills have been demonstrated to positively affect performance (e.g. Nordhaug, 1998) and productivity (e.g. Lucas, 1988). In their study of professional service firms, Hitt et al. (2001) demonstrate that human capital exhibits a curvilinear (U-shaped) effect on performance.

Numerous studies have shed light on the role of top management teams (TMT) on performance, considering the experience of individuals, their personal networks as well as the heterogeneity of the composition of the TMT. Florin et al. (2003) highlight the role of experience and personal networks on sales growth and return on sales in high-growth ventures. Nadkarni (2010) investigates the relationship between personality of the CEO and performance of the business process outsourcing industry. Auh \& Menguc (2006) demonstrate that top management team experience diversity moderates the effect of customer orientation on organizational performance.

The consequences of individuals' mobility on performance have been discussed in conceptual literature (e.g. Dess \& Shaw, 2001). The effects of mobility on performance and on innovative performance respectively have empirically analyzed in the services industries (e.g. Somaya et al., 2008) and in public organizations (e.g. Herrara et al., 2010).

Literature has also paid attention to the link between HR practices and performance at firm-level in terms of productivity and efficiency (e.g. Becker \& Gerhart, 1996; Youndt et al., 1996), financial performance (e.g. Collins \& Clark, 2003; Delery \& Doty, 1996) and more recently on innovation performance (Chen \& Huang, 2009). Training has been proved to be positively related to innovation (e.g. Ballot et al., 2001). Other examined HR practices generally encompass staffing (i.e. selecting and allocating the most competent and qualified workforce to missions and tasks), discretion and participation, performance appraisal and compensation. In a similar vein, Chen \& Huang (2009) find evidence that knowledge management capacity plays a mediating role between strategic human resource practices and innovation performance.

Some studies have investigated the relationship between human capital and performance, using innovation as an antecedent to performance. Selvarajan et al. (2007) find convincing evidence that human capital enhancement paves the way for greater innovativeness, which in turn affects firm performance. Collins \& Smith (2006) show that commitment-based human resource practices create a social climate for trust, cooperation, and the development of shared codes and language that in turn boosts the firm's capability to exchange and combine knowledge. In their study of 136 high technology companies, they demonstrate that climates of trust, cooperation, and shared codes and language were all significantly related to revenue from new products and services and sales growth, and these relationships were mediated by the level of knowledge exchange and combination among knowledge workers. Based on 
empirical evidence for Spanish firms, Garcia-Morales et al. (2007) find convincing evidence that personal mastery (i.e. self-esteem, satisfaction and skills development) positively influences organizational performance, both directly and indirectly through organizational learning and innovation.

From the perspective of the innovation process, based on a case study research in a large chemical firm, Nerkar \& Paruchuri (2005) indicate that the position of individual inventors within intra-firm knowledge network affects the likelihood with which the knowledge produced by the individual is actually used in the R\&D activities.

With respect to innovation outcome, the effect of network board capital (operationalized by education and personal networks) on the magnitude of the innovation outcome (i.e. radical versus incremental innovation) has also been the subject of recent empirical investigation (Wincent et al., 2010). In high tech firms, Beckman (2006) analyzes how the composition of founding teams shapes firm's behaviors and ambidexterity. Firms whose founding teams are composed of individuals with similar prior experience and affiliations tend to engage in exploitation while firms whose founders hold disparate experiences generate unique ideas and hold contacts that foster exploration. Her findings suggest that firms whose founding teams have both common and prior affiliations possess advantages that allow them to grow.

\subsection{Structural Capital, Innovation and Performance}

Several elements of structural capital emerge in studies on innovation determinants, process and performance at firm-level: intellectual property, documented information and codified knowledge, information systems, knowledge management, organizational structure and culture.

Intellectual property and more specifically patents can be an input to the innovation process and is generally acknowledged as an output measure of R\&D and innovation (Lev, 2001). On the one hand, formal protection instruments such as patents hinder uncontrolled use of invention. On the other hand, they contribute to the voluntary diffusion of proprietary knowledge to other parties and therefore can represent valuable knowledge inputs for firms.

With respect to the output perspective, there is an abundant literature supporting the existence of a positive relationship between $\mathrm{R} \& \mathrm{D}$ spending and patenting, in various manufacturing industries (e.g. Pakes and Griliches, 1984; Cardinal and Hatfield, 2000 for pharmaceutical firms; Ahuja and Katila, 2001 in the chemical industry; Hagedoorn and Duysters, 2002 for the computer industry cited by Artz et al., (2010) covering multiple industries).

Patents are, to a certain extent, a specific form of knowledge spillover from which firms can benefit. In the same vein, firms may access information from various parties, namely market players (suppliers, customers, competitors, consulting firms), institutional players (research and technology organizations) and other sources such as conferences, fairs and professional associations, as the Oslo Manual categorizes these information sources. The integration of external knowledge at various stages of the innovation process acts as a catalyst of the innovation performance (e.g. Katila \& Ahuja, 2002; Katila, 2002). Laursen \& Salter (2006) demonstrate a curvilinear relationship - taking the form of an inverted U-shape- between 
depth (intensity) and breadth (variety) of information sourcing and innovation performance in manufacturing firms. Adopting a specialized market-driven search strategy increases innovation success, particularly when combined with internal R\&D investments (Sofka \& Grimpe, 2010).

Information and communication technologies are generally admitted as important drivers of innovation, taking the form of new services (e.g. online banking), new marketing channels (e.g. electronic advertisement), new commercialization practices (e.g. e-commerce), and performance (revenues from innovative sales and efficiency gains through improved work practices, cost reductions) across industries. Information systems and computer science scholars have unfolded the "information and communication technologies" black box to provide convincing evidence of the effects of specific items (e.g. Customer relationship management or enterprise resource planning software and processes) on organizational performance, following the seminal works of Brynjolfsson \& Hitt (2000).

Knowledge management (KM) is concerned with the identification, acquisition, generation, retention of knowledge that is valuable for the organization. Knowledge management covers the management of both tacit and explicit knowledge possessed by the firm, as well as the mechanisms to create knowledge within firms. Nonaka (1994) identifies four modes of knowledge creation: from tacit to explicit (externalization), from tacit to tacit (socialization), from explicit to tacit (internalization) and from explicit to explicit (combination). Undoubtedly, knowledge management is closely intertwined with innovation management, as the potential of firms to generate innovations is dependent on the prior accumulation of knowledge they have absorbed (Fiol, 1996), in line with the concept of "absorptive capacity" introduced by Cohen \& Levinthal (1990) and later reconceptualized by Zahra \& George (2002). In a similar vein, a recent and noteworthy conceptualization attempt identifies six knowledge capacities as the firm's critical capabilities of managing internal and external knowledge in open innovation processes: inventive, absorptive, transformative, connective, innovative and desorptive capacity (Lichtenthaler \& Lichtenthaler, 2009). An extant literature focuses on the knowledge management systems and tools (e.g. knowledge repositories) that support the innovation process, from the ideation stage to the commercialization phase. Empirical evidence on the effect of knowledge management on innovation outcome and performance remains relatively scarce. Notable exceptions are studies by Marques \& Simon (2006), which provide evidence of a positive relationship between KM and firm performance and Darroch (2005), who fails to confirm a positive link between KM and overall firm performance but indicates that firms effectively managing knowledge tend to be more innovative. The rich literature on knowledge management in general (knowledge creation and retention, KM systems, etc.) lies beyond the scope of this review which focuses on the effects of IC on performance.

As argued by Adams et al. (2006), the effect of organizational structure and culture on innovation can be traced back to Burns \& Stalker (1961). In essence, they describe a contingency approach to innovation management, according to which, an organization is "above all an adaptive system which evolves by reacting to its environment" (Becheikh et al., 2006). Organizational structure and culture comprise organizational complexity and 
administrative intensity (Damanpour, 1991), propensity to take risks (Saleh \& Wang, 1993, cited by Adams et al., 2006), existence of a shared vision (Pinto \& Prescott, 1988; West, 1990; cited by Adams et al., 2006), and level of autonomy (Amabile, 1998).

\subsection{Relational Capital, Innovation and Performance}

Intra-firm and inter-firm cooperation and their effects on performance have been widely discussed in the literature. The Open innovation model (Chesbrough, 2003), suggesting that accessing knowledge across the boundaries of the firm greatly speeds up the innovation process and increases the innovative potential of the firm, has further fuelled the publication of both conceptual and empirical works. So far, the literature has mainly concentrated on the effects of relational capital on performance (e.g. Asakawa \& Nakamura, 2010; Martin \& Eisenhardt, 2010), and to a lesser extent, on the innovation process (Emden et al., 2006) and outcome (Monjon \& Waelbroeck, 2003; Tether, 2002).

A large body of literature has focused on the rationales for and the effects of cooperation in manufacturing industries. Although services have long been neglected in micro-level innovation studies, a new stream of contributions has emerged during the last decade. These empirical studies adopt a comparative approach or examine services and manufacturing firms jointly.

Co-operation for innovation activities is often motivated by the willingness to gain access to new or foreign markets, to share the risks and costs associated with R\&D activities, and/or to benefit from complementary skills and knowledge. Firms may establish different co-operation agreements, allowing them to access a wide base of external knowledge. Overall, most studies have acknowledge either positive (e.g. Baum et al, 2000; Shan et al., 1994; Stuart, 2000) or insignificant (e.g. Love \& Roper, 2001) effects of co-operation on the innovation process. Multiple simultaneous cooperative relations enable checking the reliability, correctness, timeliness and completeness of the information circulated (Schilling and Phelps, 2007).

Co-operation for innovation activities may serve different purposes, depending on the partners involved. Based on a series of case study interviews, Emden \& Calantone (2006) propose a theoretical framework to select co-operation partners for new product development activities so as to maximize the value creation potential. Their model unveils three phases: the technological, followed by the strategic and the relational alignment. Whereas the first one triggers the partner selection, the last two are critical for the transfer and integration of critical know-how and to create value from the collaboration.

Co-operation with customers has also been widely explored, amongst others in the marketing literature. The literature on lead users (e.g. Von Hippel, 1986) provides evidence on the benefits of such co-operation and an extensive review of this literature lies beyond the scope of this review. Supplier cooperation is usually associated with efficiency, input quality improvement (Hagedoorn, 1993) and time-to-the-market reduction (Clark, 1989). Suppliers are also a source of specialized knowledge and skills, which can adequately complement the capabilities of the firms (Un et al., 2010). 
Co-opetition, term originally coined by Brandenburger \& Nalebuff (1996), refers to the relationship between firms that involves simultaneously co-operation and competition. Rationales for cooperating with competitors are threefold: the willingness to share risks and costs of innovation activities, the quest for synergistic effects through the pooling of resources (Das and Teng, 2000; Huang et al., 2009) and the compliance with new regulatory constraints or industry standards (Nakamura, 2003). Although competitors may be critical sources of innovation and organizational learning (Afuah, 2000), they also target the same markets and possess relatively similar, at least to some extent, skills and competencies. To properly operate, such cooperation therefore implies the development of complex relationships and mechanisms to protect the respective knowledge base, while fostering knowledge exchange between competitors. Given the knowledge proximity between co-opetitors, such cooperation may also endanger the creation of new knowledge and therefore restrict radical product developments, thereby affecting innovation outcome (Knudsen, 2007).

Firms may also engage in cooperative agreements with science partners. Science partners (universities, research and technology organizations) are providers of applied or fundamental research capacities and develop scientific knowledge, which can be highly relevant for frontend stages of development. However, knowledge generated by such partners has been criticized as being far from application, therefore requiring substantial investments to fully exploit it in the later stages of the innovation process (e.g. Sokfa \& Grimpe, 2010).

Knowledge intensive business services, which form the backbone of the knowledge parallel infrastructure (Hertog, 2000), may contribute to the innovation process as innovation partners. Kuusisto and Meyer (2003) claim that this parallel knowledge infrastructure "plays a crucial role in the creation and commercialization of new products, services and processes. They are vital carriers, shapers and creators of innovations, whether they are technological or managerial in nature”.

Based on a large-scale empirical study on Belgian firms, Faems \& Van Looy (2005) indicate that the impact on innovative performance, measured as the proportion of turnover attributed to new products, differs depending on the nature of the partners involved. In a cross-country and sector comparison, Chang (2003) argues that the types of inter-firm cooperation enhancing innovative performance vary across sectors and countries. Similarly, Asakawa \& Nakamura (2010) indicate that co-operation effects on performance are conditional upon the nature of R\&D activities jointly undertaken.

Studying the effects of close relationships between firms belonging to the B2B software industry and surrounding actors (i.e. customers, suppliers, research organizations), Hsueh et al. (2010) find a positive influence of market players (customers and suppliers) but fail to identify the effect of research organizations on service innovation performance.

So far, literature provides mixed evidence on the effects of inter-firm cooperation on the degree of novelty of the innovation outcome. Some argue that inter-firm cooperation positively affects the degree of novelty of innovation (e.g. Kaufmann \& Tödling, 2001). Conversely, Monjon \& Waelbroeck (2003) find that such co-operation has a negative effect 
on the degree of novelty of innovation. Most of these co-operation studies focus on the manufacturing sector. Co-opetition has been demonstrated to affect innovation novelty either positively (e.g. Tether, 2002) or negatively (Monjon \& Waelbroeck, 2003). Similarly, research on co-operation with science partners provides mixed results on its effect on innovation novelty, and is almost inexistent in service industries.

With respect to intra-firm cooperation, Tsai \& Goshal (1998) shed light on the role of social interaction and trust on extent of knowledge exchange, which in turn affect product innovation. Based on a multiple cases research, Martin \& Eisenhardt (2010) conclude that a corporate-centric approach to foster intra-firm cooperation may generate less fruitful collaborations than if spontaneously originated by business unit members.

\section{Conclusions}

This literature review aimed at shedding light on the existing body of knowledge related to the relationships between intellectual capital, innovation and performance. A systematic approach has been adopted to conduct this literature review. The findings have been presented using the widely acknowledged intellectual capital classification scheme as a framework. Furthermore, two main dimensions of innovation have been considered: innovation as a process and innovation as an outcome (Crossan \& Apaydin, 2010). Innovation as a process focuses on the drivers (why innovate), sources (inputs for innovation) and locus (where innovation takes place) of innovation, where innovation as an outcome pertains to the type of innovation (product, process, organizational, marketing), the magnitude (incremental or radical) and the referent (firm, market, industry). Performance has been defined as a multidimensional concept, encompassing financial and non financial aspects.

A number of points emerge from the review of the relevant literature.

First, the link between intellectual capital and performance has been scrutinized from two main and complementary perspectives. The first one is based on factual and audited information and provides an overall measure of the efficiency of intellectual capital employed. While the overall measure $\left(\mathrm{VAIC}^{\mathrm{TM}}\right.$ ) is generally found to be positively related to performance measures, mixed results are obtained for both human capital and structural capital efficiency. The second takes a radically different approach and relies on subjective and perceptual measures of both intellectual capital and performance. A limited set of studies sit between these two extremes and make use of factual measures of performance. Altogether, their findings confirm the central role of human capital, as it directly influences the other constructs and indirectly affects performance. The effects of structural and relational capital are more challenging and inconclusive. No clear cut results are available regarding the interrelationships between these constructs. In addition, the interaction effects on performance deserve further investigation, as prior findings are limited and contradictory.

Second, few empirical studies have concentrated on the influence of intellectual capital (as a whole) on innovation, either as a process or as an outcome. A very limited set of studies (e.g. Chen et al., 2006; Tseng \& Goo, 2005; Wu et al., 2007) have investigated the effects of 
intellectual capital on innovation, which they consider as an antecedent to firm performance. These studies provide mixed results on the interrelationships between the different IC components and their interaction effects on performance. Hence, this area deserves further research. Interestingly, these studies explore these relationships in high tech manufacturing firms despite the growing importance of services. Furthermore, IC has an obvious inherent role in services as they are characterized by a close interaction between providers and users in the production process and the intrinsic customization process that may be knowledge-intensive and is highly dependent on individuals.

Third, the effects of individual component of intellectual capital on performance have received differentiated attention depending on the component under scrutiny. Yet much remains to be understood as to the influence of intellectual capital on innovation process, outcome and performance.

Human capital and its effects on the innovation process have been deeply investigated. Understanding and measuring the contribution of both individuals and teams to innovation (process and outcome) has been scrutinized from different angles, to name a few, efforts in $R \& D$, propensity of individuals to innovate, demographic characteristics including education levels, composition of teams, role of management, level of autonomy and attitudes to work.

Likewise, since the seminal work of Becker (1964), the relationship between human capital and performance has been investigated from various perspectives, in the economic, (strategic) human resource management and organizational learning literature.

To date, research on the role of structural capital on innovation has mainly concentrated on information systems and patents. The impact of information systems (i.e. technologies and processes to facilitate their usage and adoption) on organizational performance is generally acknowledged. Patents are assimilated to intermediary outputs of the innovation process or potentially tradable elements. This observation mirrors the considerable focus on high-tech manufacturing industries of innovation studies. Therefore, the role of structural capital on the innovation process in service industries, both from the input (rather neglected so far, also in manufacturing firms) and output perspectives, deserves further investigation.

Concurrently with the advent of the Open Innovation, touted as the superior if not the only innovation model, the relationships an organization develops with suppliers, customers, competitors, research organizations have been increasingly explored. Convincing evidence on the effects of co-operation with customers and suppliers on performance has been found. Yet, the role of intra-firm co-operation, co-opetition and co-operation with science partners both on innovation outcome (e.g. how such co-operation impacts the degree of novelty of innovation) and on innovation process may deserve further investigation. Moreover, most of the studies in this field adopt manufacturing firms as empirical settings and usually focus on product innovations to the detriment of other types of innovations (services, organizational, process, etc.). So far, empirical evidence for service sector firms remains scarce. Further research could therefore concentrate on services so as to explore whether similar findings also apply in this context. 


\section{References}

Abdolmohammadi, M. (2005). Intellectual capital disclosure and market capitalization. Journal of Intellectual Capital, 6(3), 397-416.

Adams, R., Bessant, J. \& Phelps, R. (2006). Innovation management measurement: a review. International Journal of Management Reviews, 8(1), 21-47.

Ahonen, G. (2000). Generative and commercially exploitable intangible assets. In Classification of intangibles. Ed J.E. Gröjer and H. Stolowy, pp 206-214. Paris: HEC School of Management.

Afuah, A. (2000). How much do your 'co-opetitors' capabilities matter in the face of technological change? Strategic Management Journal, 21 (3), 387-404.

Ahuja, G. (2000). Collaborative networks, structural holes, and innovation: A longitudinal study. Administrative Science Quarterly, 45, 425-455.

Ahuja, G. and Katila, R. (2001). Technological Acquisition and the Innovative Performance of Acquiring Firms: A Longitudinal Study. Strategic Management Journal, 22(3), 197-220.

Amabile, T.M. (1998). How to kill creativity. Harvard Business Review, September-October, 77-87.

Appuhami, R. (2007). The Impact of Intellectual Capital on Investors' Capital Gains on Shares: An Empirical Investigation of Thai Banking, Finance \& Insurance Sector. International Management Review, 3(2), 14-25.

Artz, K. W., Norman, P. M., Hatfield, D.E. and Cardinal, L.B. (2010). A longitudinal study of the impact of R\&D, patents, and product innovation on firm performance. Journal of Product Innovation Management, 27(5), 725-740.

Asakawa, K., Nakamura, H. \& Sawada, N. (2010). Firms' open innovation policies, laboratories' external collaborations, and laboratories' $\mathrm{R} \& \mathrm{D}$ performance. $R$ and $D$ Management, 40(2), 109-123.

Atkinson, A. A., Waterhouse, J. H., \& Wells, R. B. (1997). A Stakeholder Approach to Strategic Performance Measurement. Sloan Management Review. Spring 1997, 25-37.

Auh, S. and Menguc, B. (2006). Diversity at the executive suite: A resource-based approach to the customer orientation - Organizational performance relationship. Journal of Business Research, 59(5), 564-572.

Ballot, G., F. Fakhfakh, \& Taymaz, E. (2001). Firms' Human Capital, R\&D and Performance: A Study on French and Swedish Firms. Labour Economics, 8(64), 443-462.

Baum, J.A.C., Calabrese, T. \& Silverman, B.S. (2000). Don’t Go It Alone: Alliance Network Composition and Startups' Performance in Canadian Biotechnology. Strategic Management Journal, 21(3), 267-294.

Barney, J.B. (1991). Firms resources and sustained competitive advantage. Journal of 
Management, 17 (1), 99-120.

Becheikh, N., R. Landry, \& Amara, N. (2006). Lessons from innovation empirical studies in the manufacturing sector: A systematic review of the literature from 1993-2003. Technovation, 26(5-6), 644-664.

Becker, B. E., and Gerhart, B. (1996). The impact of human resource management on organizational performance: Progress and prospects. Academy of Management Journal, 39, 779-801.

Becker, 1964. Human capital. New York: Columbia University Press.

Beckman, C. M. (2006). The influence of founding team company affiliations on firm behavior. Academy of Management Journal, 49(4), 741-758.

Bollen, L., Vergauwen, P. \& Schnieders, S. (2005). Linking intellectual capital and intellectual property to company performance. Management Decision, 43 (9), 1161-85.

Bontis, N. (1998). Intellectual Capital: An exploratory study that develops measures and models. Management Decision, 36 (2), 63-76.

Bontis, N. (1999). Managing organizational knowledge by diagnosing intellectual capital: Framing and advancing the state of the field. International Journal of Technology Management, 18(5), 433-462.

Bontis, N., M. M. Crossan, \& Hulland, J. (2002). Managing an organizational learning system by aligning stocks and flows. Journal of Management Studies, 39(4),437-469.

Bontis, N., Know, W.C. \& Richardson, S. (2000). Intellectual capital and business performance in Malaysian industries. Journal of Intellectual Capital, 1 (1), 85-100.

Brandenburger, A.M., Nalebuff, B.J. (1996). Co-opetition. Doubleday, New York.

Brennan, N. (2001). Reporting intellectual capital in annual reports: evidence from Ireland. Accounting, Auditing and Accountability Journal, 14(4), 423-436.

Brynjolfsson, E. and Hitt, L. M. (2000). Beyond computation: Information technology, organizational transformation and business performance. Journal of Economic Perspectives 14(4), 23-48.

Burns, T., and Stalker, G.M. (1961). The Management of Innovation. Tavistock, London.

Cabrita, M. and Bontis, N. (2008). Intellectual capital and business performance in the Portuguese banking industry. International Journal of Technology Management, 43 (1-3), 212-37.

Calisir, F., Gumussoy, C. A., Bayraktaroglu, A. E. \& Deniz, E. (2010). Intellectual capital in the quoted Turkish ITC sector. Journal of Intellectual Capital, 11(4), 538-554.

Campbell, J.P. (1977). On the nature of organizational effectiveness. New perspectives on organizational effectiveness. P.S. Goodman, J.M. Pennings and associates. San 
Francisco-London, Jossey-Bass publishers, 13-35.

Cardinal, L.B. and Hatfield, D.E. (2000). Internal Knowledge Generation: The Research Laboratory and Innovative Productivity in the Pharmaceutical Industry. Journal of Engineering \& Technology Management,17(3-4), 247-271.

Chan, K.H. (2009a). Impact of intellectual capital on organizational performance: an empirical study of companies in the Hang Seng Index (Part I).The Learning Organization, 16 (1), 4-21.

Chan, K.H. (2009b). Impact of intellectual capital on organizational performance: an empirical study of companies in the Hang Seng Index (Part II). The Learning Organization, 16 (1), 22-39.

Chang, Y. C. (2003). Benefits of co-operation on innovative performance: Evidence from integrated circuits and biotechnology firms in the UK and Taiwan. R and D Management 33(4), 425-437.

Chen, M., Cheng, S. \& Hwang, Y. (2005). An empirical investigation of the relationship between intellectual capital and firms' market value and financial performance. Journal of Intellectual Capital, 6(2), 159-76.

Chen, C. J. and Huang, J. W. (2009). Strategic human resource practices and innovation performance - The mediating role of knowledge management capacity. Journal of Business Research, 62(1), 104-114.

Chen, C. J. and Y. F. Huang (2010). Creative workforce density, organizational slack, and innovation performance. Journal of Business Research, 63(4), 411-417.

Chen, M. H. and Wang, M. C. (2008). Social networks and a new venture's innovative capability: The role of trust within entrepreneurial teams. $R$ and $D$ Management, 38(3), 253-264.

Chen, Y.S., Lin, M.J.J. and Chang, C.-H. (2006). The Influence of Intellectual Capital on New Product Development Performance - The Manufacturing Companies of Taiwan as an Example. Total Quality Management, 17(10), 1323-1339.

Chendhall, R.H. (1997). Reliance on manufacturing performance measures, total quality management and organizational performance. Management Accounting Research, 8, 187-206.

Chesbrough, H. ( 2003). Open Innovation: the new Imperative for Creating and Profiting from Technology. Harvard Business School Press, Boston, MA.

Chesbrough, H. W. (2006). New puzzles and new findings. In H. W. Chesbrough \& W. Vanhaverbeke \& J. West (Eds.), Open innovation: Researching a new paradigm, pp.15-33. Oxford: Oxford University Press.

Choo, C.W. and Bontis, N. (2002). The Strategic Management of Intellectual Capital and Organizational Knowledge, New York: Oxford University Press. 
Clark, K. (1989). Product scope and project performance: the effect of parts strategy and supplier involvement on product development. Management Science, 35 (10), 1247-1263.

Cohen, W. and Levinthal, D. (1989).Innovation and learning: the two faces of R\&D. Economic Journal, 99(397), 569-596.

Cohen, S. and Kaimenakis, N. (2007). Intellectual Capital and Corporate Performance in Knowledge-intensive SMEs. The Learning Organisation, 14(3), 241-262.

Coleman, J. (1988). Social capital in the creation of human capital. American Journal of Sociology, 94, 95-120.

Collins, C.J. and Clark K.D. (2003). Strategic human resource practices, top management team social networks, and firm performance: the role of human resource in creating organizational competitive advantage. Academy of Management Journal, 46(6), 740-51.

Collins, C. J. and Smith, K. G. (2006). Knowledge exchange and combination: The role of human resource practices in the performance of high-technology firms. Academy of Management Journal, 49(3), 544-560.

Cook, D.J., Mulrow, C.D., and Haynes, R.B. (1997). Systematic reviews: synthesis of best evidence for clinical decisions. Annals of Internal Medecine, 126 (5), 379-380.

Crossan, M. M. and Apaydin, M. (2010). A multi-dimensional framework of organizational innovation: A systematic review of the literature. Journal of Management Studies, 47(6), 1154-1191.

Damanpour, F. (1991). Organizational innovation: a meta-analysis of effects of determinants and moderators. Academy of Management Journal, 34, 555-590.

Darroch, J. (2005). Knowledge management, innovation and firm performance. Journal of Knowledge Management, 9(3), 101-115.

Das, T.K. and Teng, B.-S. (2000). A resource-based theory of strategic alliances. Journal of Management, 26 (1), 31-60.

Davis, H.Z. and Peles, Y.C. (1993). Measuring equilibrating forces of financial ratios. The Accounting review, 68(4), 725-747.

Delery, J.E and Doty, D.H. (1996). Modes of theorizing in strategic human resource management: tests of universalistic, contingency, and configurational performance predictions. Academy of Management Journal, 39(4),802-35.

Denyer, D. and Neely, A. (2004). Introduction to special issue: innovation and productivity performance in the UK. International Journal of Management Reviews, 4/5, 131-135.

Dess, G. G. and Shaw, J. D. (2001). Voluntary turnover, social capital, and organizational performance. Academy of Management Review, 26(3), 446-456.

Diez, J. M., Ochoa, M., L., Prieto, M.B. \& Santidrian, A. (2010). Intellectual capital and 
value creation in Spanish firms. Journal of Intellectual Capital, 11(3), 348-367.

Drucker, P.F. (1993). The rise of the knowledge society. Wilson Quarterly, 17 (2), 52-70.

Edvinsson, L. and Malone, M. (1997). Intellectual Capital: Realising Your Company’s True Value by Finding its Hidden Brainpower. Harper Collins, New York, NY.

Edvinsson, L.and Sullivan, P. (1996). Developing a model for managing intellectual capital. European Management Journal, 14 (4), 356-364.

Emden, Z., Calantone, R. J. \& Droge, C. (2006). Collaborating for new product development: Selecting the partner with maximum potential to create value. Journal of Product Innovation Management, 23(4), 330-341.

Faems, D., B. Van Looy, \& Debackere, K. (2005). Interorganizational collaboration and innovation: Toward a portfolio approach. Journal of Product Innovation Management, 22(3), 238-250.

Fernández, E., Montes, J.M., \& Vasquez, C. J. (2000). Typology and strategic analysis of intangible resources. A resource-based approach. Technovation, 20(2), 81-92.

Fincham, R. and Roslender, R. 2003. Intellectual capital as management fashion: a review and critique. European accounting review, 12 (4), 753-779.

Fiol, C.M. (1996). Squeezing harder doesn't always work: continuing the search for consistency in innovation research. Academy of Management Review, 21 (4), 1012-1021.

Firer, S. and Williams, S.M. (2003). Intellectual capital and traditional measures of corporate performance. Journal of Intellectual Capital, 4(3), 348-60.

Fitzgerald, L., Johnston, R., Brignall, S., Silvestro, R. and Voss, C. (1991). Performance measurement in service business, CIMA, London.

Florin, J., Lubatkin, M. \& Schulze, W. (2003). A social capital model of high-growth ventures. Academy of Management Journal, 46(3), 374-384.

García-Morales, V. J., Lloréns-Montes, F. J. and Verdú-Jover, A. J. (2007). Influence of personal mastery on organizational performance through organizational learning and innovation in large firms and SMEs. Technovation, 27(9), 547-568.

Ghosh, S. and Mondal, A. (2009). Indian software and pharmaceutical sector IC and financial performance. Journal of Intellectual Capital, 10 (3), 369-88.

Goh, P.C. (2005). Intellectual capital performance of commercial banks in Malaysia. Journal of Intellectual Capital, 6(3), 385-96.

Grant, R. (1996). Toward a knowledge-based theory of the firm. Strategic Management Journal, 17, 109-22.

Griffith, R., E. Huergo, Mairesse, J. and Peters, B. (2006). Innovation and Productivity Across Four European countries. Oxford Review of Economic Policy, 22 (4), 483-498. 
Guimon, J. (2005). Intellectual capital reporting and credit risk analysis. Journal of Intellectual Capital, 6(1), 28-42.

Hagedoorn, J. (1993). Understanding the rationale of strategic technology partnering: interorganizational modes of co-operation and sectoral differences. Strategic Management Journal, 14 (5), 371-385.

Hayton, J. C. (2005). Competing in the new economy: The effect of intellectual capital on corporate entrepreneurship in high-technology new ventures. $R$ and $D$ Management, 35(2), 137-155.

Hertog, P. D. 2000. Knowledge-Intensive Business Services as Co-Producers of Innovation. International Journal of Innovation Management, 4, 491-528.

Hermans, R. and Kauranen, I. (2005). Value creation potential of intellectual capital in biotechnology - Empirical evidence from Finland. $R$ and D Management, 35(2), 171-185.

Herrera, L., Muñoz-Doyague, M. F. \& Nieto, M. (2010). Mobility of public researchers, scientific knowledge transfer, and the firm's innovation process. Journal of Business Research, 63(5), 510-518.

Hitt, M. A., L. Bierman, Shimizu, K. \& Kochhar, R. (2001). Direct and moderating effects of human capital on strategy and performance in professional service firms: A resource-based perspective. Academy of Management Journal, 44(1), 13-28.

Hitt, M. A., L. Bierman, Uhlenbruck, K. \& Shimizu, K (2006). The importance of resources in the internationalization of professional service firms: The good, the bad, and the ugly. Academy of Management Journal, 49(6), 1137-1157.

Hsu, Y. H. and Fang, W. (2009). Intellectual capital and new product development performance: The mediating role of organizational learning capability. Technological Forecasting and Social Change,76(5), 664-677.

Hsueh, J. T., Lin, N. P. and Li, H.C. (2010). The effects of network embeddedness on service innovation performance. Service Industries Journal, 30(10), 1723-1736.

Huang, Y.-A., Chung, H.-.J. and Lin, C. (2009). R\&D sourcing strategies: Determinants and consequences. Technovation, 29, 155-169.

Ittner, C.D. and Larcker, D.F. (1998). Are non financial measures leading indicators of financial performance? An analysis of customer satisfaction. Journal of Accounting Research, 36, suppl.1998, 1-35.

Ittner, C.D. and Larcker, D.F. (1997). Quality strategy, strategic control systems and organizational performance. Accounting, Organizations and Society, 22(3/4), 293-314.

Jackson, S.E. and Schuler, R.S. (1995). Understanding human rsource management in the context of organizations and their environments. In: M. Rosenweig/L. Porter (eds.): Annual Review of Psychology. Palo Alto, CA: Annual Reviews: 237-264. 
Jardon, C. M. and Martos, M. S. (2009). Intellectual capital and performance in wood industries of Argentina. Journal of intellectual capital, 10 (4), 1469-1930.

Jassawalla, A. R. and Sashittal, H. C. (1998). An examination of collaboration in high-technology new product development processes. Journal of Product Innovation Management, 15(3), 237-254.

Kamath, G.B. (2007). The intellectual capital performance of Indian banking sector. Journal of Intellectual Capital, 8(1), 96-123.

Kamath, G.B. (2008). Intellectual capital and corporate performance in Indian pharmaceutical industry. Journal of Intellectual Capital, 9 (4), 684-704.

Kaplan, R. S. and Norton, D. P. (1992). The Balanced Scorecard - Measures that Drive Performance. Harvard Business Review, January - February, pp. 71-79.

Kaufmann, A., and Tödling, F. (2001). Science-industry interaction in the process of innovation: the importance of boundary-crossing between systems. Research policy, 30, 791-804.

Katila, R. (2002). New product search over time: Past ideas in their prime? Academy of Management Journal, 45, 995-1010.

Katila, R. and Ahuja, G. (2002). Something old, something new: A longitudinal study of search behavior and new product introduction. Academy of Management Journal, 45, 1183-1194.

Kianto, A. (2007). What do we really mean by dynamic intellectual capital?. International Journal of Learning and Intellectual Capital, 4 (4), 342-56.

Knudsen, M. P. (2007). The relative importance of interfirm relationships and knowledge transfer for new product development success. Journal of Product Innovation Management, 24(2), 117-138.

Kuusisto, J. and Meyer, M. (2003). Insights into services and innovation in the knowledge intensive economy, Technology Review 134/2003, Tekes, Helsinki.

Laursen, K. and Salter, A. (2006). Open for innovation: The role of openness in explaining innovation performance among U.K. manufacturing firms. Strategic Management Journal, 27(2), 131-150.

Lepak, D. P. and Snell, S. A. (1999). The human resource architecture: Toward a theory of human capital allocation and development. Academy of Management Review 24(1),31-48.

Lev, B. (2001). Intangibles: management, measurement and reporting. Brookings Institution Press, Washington.

Lichtenthaler, U. (2009). Outbound open innovation and its effect on firm performance: Examining environmental influences. $R$ and D Management, 39(4), 317-330.

Lichtenthaler, U. and Lichtenthaler, E. (2009). A capability-based framework for open 
innovation: Complementing absorptive capacity. Journal of Management Studies, 46(8), 1315-1338.

Love, J.H. and Roper, S. (2001). Location and network effects on innovation success : evidence for UK, German and Irish manufacturing plants. Research Policy, 30, 313-332.

Lucas Jr., R. (1988). On the mechanics of economic development. Journal of Monetary Economics, 22 (1), 3-42.

Marqués, D. P. and Simon F. J. G. (2006). The effect of knowledge management practices on firm performance, Journal of Knowledge Management, 10(3), 143-156.

Martin, J. A. and Eisenhardt, K. M. (2010). Rewiring: Cross-business-unit collaborations in multibusiness organizations. Academy of Management Journal, 53(2), 265-301.

Mavridis, D. (2004). The intellectual capital performance of the Japanese banking sector. Journal of Intellectual Capital, 5 (1), 92-115.

Mention, A.-L. (2011). Intellectual capital reporting: an exploratory study on the practices in the banking industry. Journal of Management Control, 22(3), 279-309.

Meritum Project. (2002). Guidelines for managing and reporting on intangibles. available at:

www.urjc.es/innotec/tools/MERITUM\%20Guidelines.pdf

Merchant, K. and Burns, W.B.J. (1986). Measurements to cure management myopia. Business Horizons, May-June, 56-64.

Mia, L. and Clarke, B. (1999). Market competition, management accounting systems and business unit performance. Management Accounting Research, 10, 137-158.

Mol, M. J. and Birkinshaw, J. (2009). The sources of management innovation: When firms introduce new management practices. Journal of Business Research, 62(12), 1269-1280.

Monjon, S. and Waelbroeck, P. (2003). Assessing spillovers from universities to firms: Evidence from French firm-level data. International Journal of Industrial Organization, 21 (9), 1255-1270.

Mulrow, C. D. (1994). Rationale for systematic reviews. BMJ (Clinical Research Ed.) 309(6954), 597-599.

Nadkarni, S. and Herrmann, P. (2010). CEO personality, strategic flexibility, and firm performance: The case of the Indian business process outsourcing industry. Academy of Management Journal, 53(5), 1050-1073.

Nahapiet, J. and Ghoshal, S. (1998). Social capital, intellectual capital, and the organizational advantage. Academy of Management Review, 23(2), 242-266.

Nakamura, M. (2003). Research alliances and collaborations: Introduction to the special issue. Managerial and Decision Economics, 24 (2/3), 47-49.

Neely A., Adams C. and Kennerley M. (2002).The Performance Prism: The Scorecard for 
Measuring and Managing Business Success. Financial Times Prentice Hall

Nelson, R., and Winter, S.G. (1982). An Evolutionary Theory of Economic Change. Harvard University Press, Cambridge, MA.

Nerkar, A. and Paruchuri, S. (2005). Evolution of R\&D capabilities: The role of knowledge networks within a firm. Management Science, 51(5), 771-785.

Nonaka, I. (1994). A dynamic theory of organizational knowledge creation, Organizational Science 5(1), 14-37.

Nordhaug, O. (1998). Competence specificities in organizations. International Studies of Management \& Organization, 28(1): 8-29.

OECD, 2005. Oslo Manual : Guidelines for Collecting and Interpreting Innovation Data. Third edition OECD, Paris.

Pakes, A. and Griliches, Z. (1984). Patents and R\&D at the Firm Level: A First Look. In: Patents and Productivity, ed. Z. Griliches. Chicago: University of Chicago Press, 55-72.

Penrose E. (1959). The Theory of the Growth of the Firm, New York: Oxford University Press.

Phillips, L.W. (1981). Assessing measurement error in key information reports: a methodological note on organizational analysis in marketing. Journal of Marketing Research, 18, 395-415.

Pittaway, L., Robertson, M., Munir, K., Denyer, D. and Neely, A. (2004). Networking and Innovation in the UK: a Systematic Review of the Literature. London: Advanced Institute of Management Research.

Prajogo, D. I. and Ahmed, P. K. (2006). Relationships between innovation stimulus, innovation capacity, and innovation performance. $R$ and D Management, 36(5), 499-515.

Pulic, A. (1998). Measuring the performance of intellectual potential in knowledge economy, paper presented at the 2nd World Congress on Measuring and Managing Intellectual Capital, McMaster University, Hamilton.

Pulic, A. (2000). VAIC - an accounting tool for IC management. International Journal of Technology Management, 20 (5-8), 702-714.

Reed, K. K., M. Lubatkin, and Srinivasan, N. (2006). Proposing and testing an intellectual capital-based view of the firm. Journal of Management Studies, 43(4), 867-893.

Roos, G.and Roos, J. (1997). Measuring Your Company's Intellectual Performance. Long Range Planning, 30(3), 413-426.

Roslender, R. Fincham, R. 2004. Intellectual capital accounting in the UK: a field study perspective. Accounting, auditing and accountability Journal, 17(2), 178-209.

Rothwell, R. (1992). Successful industrial innovation: critical factors for the 1990s. $R$ and 
D Management, 22, 221-239.

Schilling, M.A. and Phelps, C.C. (2007). Inter-firm collaboration networks: the impact of large- scale network structure on firm innovation. Management Science, 33, 1113-1126.

Schiuma, G. S. and Lerro, A. (2008). Intellectual capital and company's performance improvement. Measuring Business Excellence, 12(2), 3-9.

Schumpeter, J. (1934). The Theory of Economic Development. Cambridge, Mass.: Harvard

University Press.

Selvarajan, T. T., Ramamoorthy, N., Flood, P. C., Guthrie, J. P., MacCurtain, S., and Liu, W. (2007). The role of human capital philosophy in promoting firm innovativeness and performance: Test of a causal model. International Journal of Human Resource Management, 18(8), 1456-1470.

Serenko, A. and Bontis, N. (2004). Meta-review of knowledge management and intellectual capital literature: Citation impact and research productivity rankings. Knowledge and Process Management, 11( 3), 185-198.

Serenko, A., Bontis, N., Booker, L., Saddedin, K. and Harding, T. (2010). A scientometric analysis of knowledge management and intellectual capital academic literature. Journal of Knowledge Management, 14 (1), 3-23.

Shan, W., Walker, G. and Kogut, B. (1994). Interfirm Cooperation and Startup Innovation in the Biotechnology Industry. Strategic Management Journal 15(5), 387-394.

Sharabati, A., Jawad, S. and N. Bontis. (2010). Intellectual capital and business performance in the pharmaceutical sector of Jordan. Management Decision, 48 (1), 105-131.

Shiu, H. (2006). The application of the value added intellectual coefficient to measure corporate performance: evidence from technological firm. International Journal of Management, 23(2), 356-65.

Smith, K. G., Collins, C. J. and Clark, K.D. (2005). Existing knowledge, knowledge creation capability, and the rate of new product introduction in high-technology firms. Academy of Management Journal, 48(2), 346-357.

Sofka, W. and Grimpe, C. (2010). Specialized search and innovation performance evidence across Europe. R and D Management, 40(3), 310-323.

Somaya, D., Williamson, I. O. \& Lorinkova, N. (2008). Gone but not lost: The different performance impacts of employee mobility between cooperators versus competitors. Academy of Management Journal, 51(5), 936-953.

Stewart, T.A. (1997). Intellectual Capital: The New Wealth of Organizations, Doubleday, New York, NY.

Stuart, T.E. (2000). Interorganizational Alliances and the Performance of Firms: A Study of Growth and Innovation Rates in a High-Technology Industry. Strategic Management Journal 
21(8), 791-811.

Sua, S., Laia, M. C. \& Huang, H.C. (2009). Healthcare industry value creation and productivity measurement in an emerging economy. Service Industries Journal, 29(7), 963-975.

Subramaniam, M. and Venkatraman, N. (2001). Determinants of transnational new product development capability: Testing the influence of transferring and deploying tacit overseas knowledge. Strategic Management Journal, 22, 359-378.

Subramaniam, M. and Youndt, M. A. (2005). The influence of intellectual capital on the types of innovative capabilities. Academy of Management Journal, 48(3), 450-463.

Sveiby, K.E. (1997), The New Organizational Wealth: Managing and Measuring Knowledge-Based Assets, Berret-Koehler, San Francisco, CA.

Tan, H.P., Plowman, D. and Hancock, P. (2007). Intellectual capital and financial returns of companies. Journal of Intellectual Capital, 8 (1), 76-95.

Teece, D. J. (2007). Explicating dynamic capabilities: The nature and microfoundations of (sustainable) enterprise performance. Strategic Management Journal, 28(13), 1319-1350.

Tether, B. S. (2002). Who co-operates for innovation, and why. An empirical analysis. Research Policy 31, 947-967.

Tidd, J., Bessant, J., \& Pavitt. K. (2005). Managing innovation. Integrating technological, market and organizational change. Hoboken: John Wiley \& Sons Inc.

Ting, I. W. K., and Lean, H. H. (2009). Intellectual capital performance of financial institutions in Malaysia. Journal of Intellectual Capital, 10(4), 588-599.

Tranfield, D., Denyer, D. and Smart, P. (2003). Towards a methodology for developing evidence informed management knowledge by means of a systematic review. British Journal of Management, 14, 207-222.

Tsai, W. and S. Ghoshal (1998). Social capital and value creation: The role of intrafirm networks. Academy of Management Journal, 41(4), 464-476.

Tseng, C.-Y. and Goo, Y.-J. J. (2005). Intellectual capital and corporate value in an emerging economy: empirical study of Taiwanese manufacturers. $R$ and D Management, 35, 187-201.

Tseng, C. Y., Kuo, H. Y. \& Chou, S. S. (2008). Configuration of innovation and performance in the service industry: Evidence from the Taiwanese hotel industry. Service Industries Journal, 28(7), 1015-1028.

Un, C. A., Cuervo-Cazurra, A., \& Asakawa, K. (2010). R\&D collaborations and product innovation. Journal of Product Innovation Management 27, 673-689.

Venkatraman, N. and Ramanujam, V. (1986). Measurement of business performance in strategy research: A comparison of approaches. The Academy of Management Review, 11 (4), 801-814. 
Vergauwen, P., Bollen, L., \& Oirbans, E. (2007). Intellectual capital disclosure and intangible value drivers: an empirical study. Management Decision, 45(7), 1163-1180.

Von Hippel, E. (1986). Lead users: a source of novel product concepts. Management Science, 32, 791-805.

Wade K., Hulland J., (2004). The Resource-Based View and Information System Research: Review, Extension and Suggestions for Future Research, MISQuarterly, 28(1), 107-142.

Wang, W.Y. and Chang, C. (2005). Intellectual capital and performance in causal models: evidence from the information technology industry in Taiwan. Journal of Intellectual Capital, 6 (2), 222-36.

Wernerfelt, B. (1984.) A Resource-Based View of the Firm. Strategic Management Journal, 5, $272-280$.

Wincent, J., Anokhin, S. \& Örtqvist, D. (2010). Does network board capital matter? A study of innovative performance in strategic SME networks. Journal of Business Research, 63(3), 265-275.

Wu, S. H., L. Y. Lin, \& Hsu, M. Y. (2007). Intellectual capital, dynamic capabilities and innovative performance of organisations. International Journal of Technology Management, 39(3-4), 279-296.

Wu, W. Y., M. L. Chang, \& Chen, C.W. (2008). Promoting innovation through the accumulation of intellectual capital, social capital, and entrepreneurial orientation. $R$ and $D$ Management, 38(3), 265-277.

Yang, S. and H. H. Kang (2008). Is synergy always good? Clarifying the effect of innovation capital and customer capital on firm performance in two contexts. Technovation, 28(10), 667-678.

Youndt, M. A., M. Subramaniam, \& Snell, S. A. (2004). Intellectual Capital Profiles: An Examination of Investments and Returns. Journal of Management Studies, 41(2), 335-361.

Youndt M.A., Snell S.A., Dean J.W., \& Lepak D.P. (1996). Human resource management, manufacturing strategy, and firm performance. Academy of Management Journal, 39(4), 836-66.

Zahra, S. A. and G. George (2002). Absorptive capacity: A review, reconceptualization, and extension. Academy of Management Review, 27(2), 185-203.

\section{Copyright Disclaimer}

Copyright reserved by the author(s).

This article is an open-access article distributed under the terms and conditions of the Creative Commons Attribution license (http://creativecommons.org/licenses/by/3.0/). 